日消外会誌 32 (11) : 2582 2585, 1999年

症例報告

\title{
慢性膵炎に伴う脺囊胞が総胆管に穿破した 1例
}

\author{
斗南病院外科 ${ }^{11}$, 北海道大学第 2 外科 ${ }^{21}$ \\ 敷島 裕之 ${ }^{122}$ 金子 行宏 ${ }^{11}$ 本原 敏司 ${ }^{1}$ \\ 塚田 守雄 ${ }^{11}$ 加藤 紘之 ${ }^{2}$
}

\begin{abstract}
慢性膵炎に伴う膵仮性囊胞が総胆管に穿破した症例を経験した . 症例は60歳の男性，平成 8年12月 慢性膵炎の急性増悪, 膵囊胞の診断にて当院入院となった .腹部 CT , 超音波検査では膵頭部に囊胞を 認め，内部は均一で囊胞壁は平滑であった .ERCPで主膵管と囊胞に交通を認め，さらに，囊胞は総胆 管に穿破していることを確認した . 臨床経過，画像診断などより慢性膵炎に伴う膵仮性囊胞と診断し たが，総胆管に穿破していることより悪性の膵囊胞性疾患も完全に否定できず，D2郭清を伴う全胃幽 門輪温存膵頭十二指腸切除を施行した . 術後病理組織診にて慢性膵炎，膵仮性囊胞の総胆管穿破との 最終診断を得た . 膵囊胞性疾患の診断と治療にあたっては慢性膵炎に伴う多彩な合併症を念頭に置く ことが重要であると考えられた .
\end{abstract}

Key words : Chronic pancreatitis, pancreatic pseudocyst, psuedocy st with rupture into the common bile duct

はじめに

炎症性膵囊胞は光の経過中に胆管狭窄，局所性門脈 圧六進などの種々の合併症を引き起こすことはよく知 られている(1) 3) .また , 囊胞が消化管をはじめとする 腹腔内臓器に穿破する報告 ${ }^{122}$ もみられるが，総胆管に 穿破することはまれである . 今回われわれは , 慢性膵 炎に伴う膵囊胞の経過観察中に膵囊胞が総胆管に穿破 した 1例を経験したので報告する．

$$
\text { 症例 }
$$

患者 : 60歳, 男性

主訴：上腹部痛

既往歴 : 55歳時, 虫垂切除

現病歴: 平成 7 年 4 月, 上腹部痛のため近医受診， 急性膵炎の診断にて入院, 保存的治療を受け軽快した . しかし, 同年11月，再び腹痛が出現し近医に再入院し た . 慢性膵炎の急性増悪，膵囊胞の診断にて保存的治 療を受けるも症状軽快せず, 精査のため12月27日当院 内科入院，手術目的にて平成 8 年 2 月 7 日当科転科と なった 。

入院時現症 : 身長 $173 \mathrm{~cm}$ ，体重 $65 \mathrm{~kg}$. 上腹部に圧痛 を認めたが腫瘤は触知しなかった 。

入院時検査所見 : 胆道系酵素と脺アミラーゼの上昇 を認めたが, 腫瘍マーカーは正常であった . 糖尿病は

< 1999年 6 月 22日受理 > 別刷請求先 : 敷島 裕之 于 060-0001 札幌市中央区北 1条西 6丁目 斗南病院 外科
Table 1 Laboratory findings

\begin{tabular}{|c|c|c|c|}
\hline T P & $6.7 \mathrm{~g} / \mathrm{dl}$ & W BC & $5,500 / \mu \mathrm{I}$ \\
\hline A lb & $3.6 \mathrm{~g} / \mathrm{dl}$ & $\mathrm{RBC}$ & $436 \times 10^{4} / \mu \mathrm{I}$ \\
\hline T-bil & $0.3 \mathrm{mg} / \mathrm{dl}$ & $\mathrm{Hb}$ & $12.0 \mathrm{~g} / \mathrm{dl}$ \\
\hline GOT & $17 \mathrm{IU} / \mathrm{l}$ & $\mathrm{Ht}$ & $37.7 \%$ \\
\hline GPT & $25 \mathrm{IU} / \mathrm{l}$ & Plt & $18.5 \times 10^{4} / \mu \mathrm{I}$ \\
\hline A LP & $347 \mathrm{IU} / l \uparrow$ & & \\
\hline$\gamma$-GT P & $139 \mathrm{IU} / l \uparrow$ & CEA & $2.7 \mathrm{mg} / \mathrm{ml}$ \\
\hline BUN & $18.3 \mathrm{mg} / \mathrm{dl}$ & CA $19-9$ & $0 \mathrm{IU} / \mathrm{l}$ \\
\hline $\mathrm{Cr}$ & $0.6 \mathrm{mg} / \mathrm{dl}$ & & \\
\hline A MY & $99 \mathrm{IU} / \mathrm{l}$ & Glu-F & 82 mg/dl \\
\hline P-A MY & $681 \mathrm{I} / \mathrm{l}$ & 75gOGT T & normal pattern \\
\hline $\mathrm{Na}$ & $138 \mathrm{mEq} / \mathrm{l}$ & & \\
\hline K & $3.7 \mathrm{mEq} / \mathrm{l}$ & PF D-test & $85.8 \%$ \\
\hline $\mathrm{Cl}$ & $99 \mathrm{mEq} / \mathrm{l}$ & & \\
\hline CRP & $0.9 \mathrm{mg} / \mathrm{dl}$ & & \\
\hline
\end{tabular}

認めず,PFD テストも正常で膵内分泌, 外分泌機能は 保たれていた (Table 1)．

腹部超音波検査 : 膵頭部に辺縁整，内部均一な径6 $\times 4 \mathrm{~cm}$ の囊胞を認めた .

腹部 CT 検査 : 膵頭部に内部均一, 辺縁が比較的整 な5x 3cm の囊胞を認めた .また，胆囊は腫大していた

(Fig. 1) .

逆行性脺一胆管造影 (ERCP) 検査 : 囊胞は主膵管と 交通していた．また，総胆管と囊胞の間にも交通を認 め, 総胆管は高度に囊胞側に変位しており総胆管は軽 度拡張していた．なおこの時採取した膵液の細胞診で 
Fig. 1 A bdominal enhanced CT scan shows the cystic lesion at the pancreatic head.

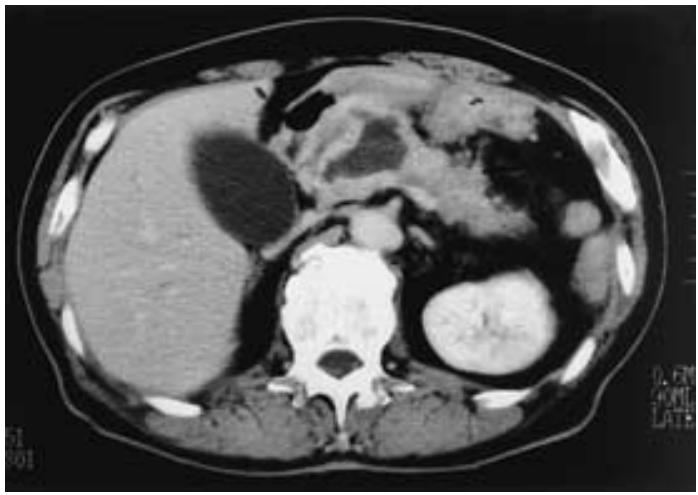

Fig. 2 ERCP shows the pancreatic cyst (arrow heads), which is communicated to the CBD (arrow). A nd T he CBD is deviation to the pacreatic cyst.

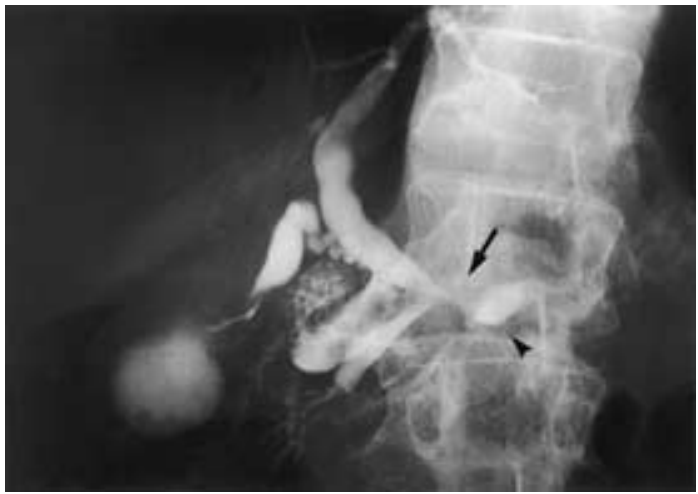

は悪性細胞は認めなかった (Fig. 2) .

腹部血管造影では膵に悪性腫瘍を示唆する所見はな く門脈にも異常所見は認めなかった．以上より脺囊胞 が総胆管に穿破した慢性脺炎と診断したが，総胆管に 穿破していることより粘液産性膵腫瘍など腫瘍性悪性 疾患も否定できず手術を施行した .

手術所見：膵頭部前面の上縁に径約 $5 \mathrm{~cm}$ 大の囊胞 を認めた．穿刺すると内容液は淡黄色, 漿液性で造影 剂を注入すると総胆管が造影され囊胞と総胆管との交 通を確認した (Fig.3) .また, 囊胞と総胆管との瘻孔 を直接確認した . 囊胞直下の膵実質に硬結を触れ，こ の部と囊胞壁の一部を術中迅速病理組織診に提出した が , 悪性所見は認められなかったものの確診は得られ ず,D2郭清を伴う全胃幽門輪温存膵頭十二指腸切除を 施行した .
Fig. 3 Intra-operative cystgraphy demonstrates the fistula to the CBD (arrow).

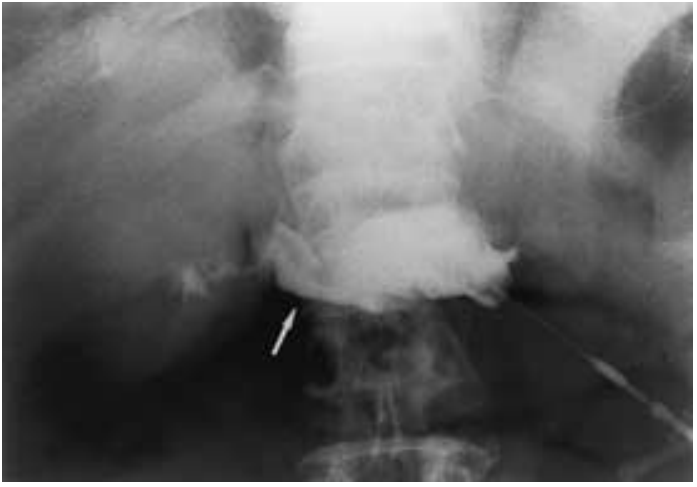

Fig. 4 Macroscopic view of the resected specimen show s the fistula (arrow) on the CBD.

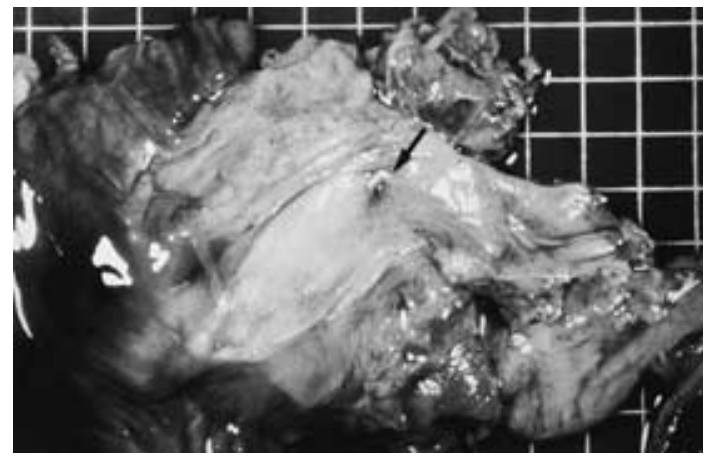

摘出標本所見：膵は全体に硬く特に囊胞直下では硬 かったが，明らかな腫瘍は認めなかった．また，総胆 管に膵囊胞とつながる瘻孔を認め，同部で総胆管は狭 小化していた (Fig.4).

病理組織学的所見 : 膵管はプロテインプラーグで満 たされ拡張し，光の周囲には線維化を伴っており，慢 性膵炎の像を呈していた (Fig. 5一A) .また，術中，囊 胞直下に触れた硬結は炎症細胞の集塊と肉芽組織とか ら成り, 腫瘍性病変は認められなかった (Fig.5-B). なお，囊胞壁は上皮成分の欠如した仮性囊胞であった 。 考察

いわゆる脺囊胞性疾患は腫瘍性と非腫瘍性に大別さ れ，弚れ光れがさらに細かく分類されているが4，弚の 診断と治療には困難を感ずる症例に遭遇することもま れではない .

膵囊胞は種々の臓器，部位に穿破することはよく知 られていることである . 炎症性膵囊胞では腹腔内はも 
Fig. 5 Histologic findings of the resected specimen shows protein plug in delatated pancreatic duct (A ), inflammatory cellular infiltration and granulation (B).
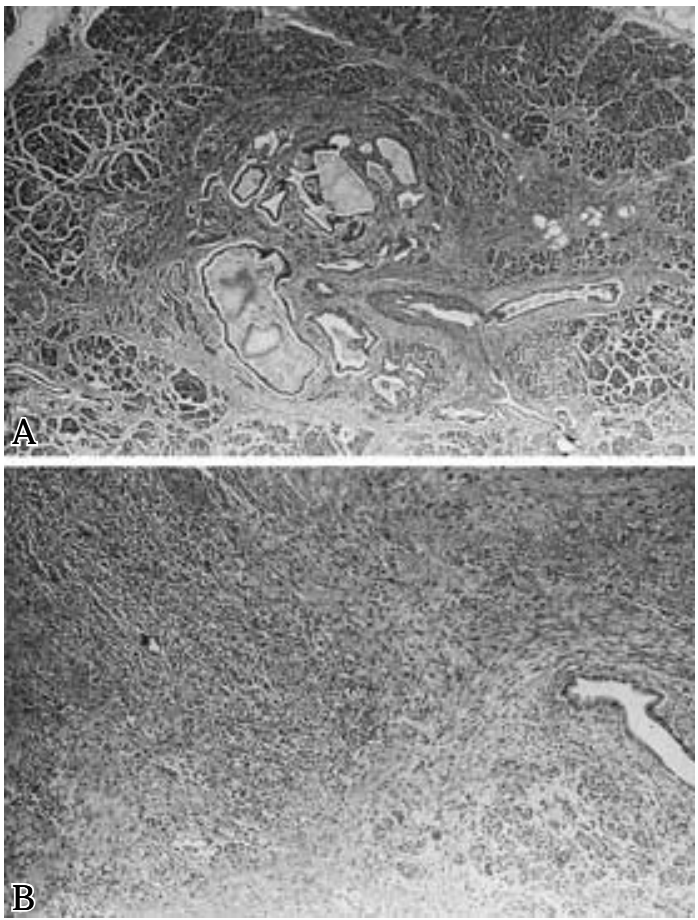

ちろんのこと胃，十二指腸，大腸などの消化管に穿破 することが多く, 脾, 縦隔, 胸腔などにも認められ $3^{122)}$. 一方, 腫瘍性膵囊胞では粘液産生脺腫瘍の特徵 の1つとして総胆管に穿破することがあ(げられる ${ }^{5)}$.

今回，我々が経験した症例は臨床経過，検査所見， CT ,エコーなどの画像所見より慢性脺炎に伴ういわゆ る炎症性脺囊胞の診断であった .CT ,エコー上囊胞壁 の腫瘍性変化は認められず, 細胞診も陰性で悪性所見 に乏しかった．しかし ERCP にて囊胞が総胆管に穿破 していることが判明し悪性の腫瘍性脺囊胞も疑われ た . 腫瘍性膵囊胞では粘液産生脺腫瘍において総胆管 に穿破する報告が散見されるが(5) 7)，炎症性膵囊胞で は胆管狭窄はよく見られる合併症であるが(19)，筆者ら が医学中央杂倠誌および Med line で検索した限りでは， これまでに総胆管穿破の報告はなかったからである．

以上より，本症例では膵囊胞の他藏器穿破の過去の 報告例より悪性の腫瘍性脺囊胞も完全には否定できず 手術に臨んだ . 術中所見では慢性脺炎に伴う膵囊胞の 印象であったが，囊胞直下の膵臓実質に硬結があり同
部の術中迅速病理組織診で良悪性の最終的鑑別は困難 で,D2リンパ節郭清を伴う全胃幽門輪温存膵頭十二指 腸切除を施行した．本症例では囊胞が総胆管に穿破し ており胆道，十二指腸を温存した膵頭部切除 ${ }^{10)}$ は不可 能であり，全胃幽門輪温存膵頭十二指腸切除はやむお えない術式だったと思われるが，D2リンパ節郭清は過 大侵襲であり結果的には不適切だったと反省させられ る。

また，粘液産生膵腫瘍では粘液貯留による膵管壁の 機械的な破綻が生じ，他藏器に穿破し内瘻を形成し腫 瘍が表層性に進展していくといわれている5). 粘液産 生膵囊胞が総胆管に穿破した場合，粘稠な粘液により 閉塞性黄疸を生じたり，胆道造影で総胆管に粘液によ る透亮像が得られるはずである . 本症例では囊胞が総 胆管に穿破していたこと以外は，慢性膵炎に伴う脺囊 胞であり，他に検査所見，画像診断上特徵的な所見は なかった .この点からも術前診断をもう少し詳細に検 討しておく必要があったと思われる.

膵囊胞性疾患の診断と治療にあたっては腫瘍性か非 腫瘍性か，腫瘍性であればその良悪性の鑑別が重要で あり適確な診断のもと適切な治療がなされなければな らない．本症例のように慢性脺炎に伴う膵囊胞が総胆 管に穿破することも起こりえることを銘記すべきであ り，炎症性膵囊胞性疾患の手術においては慢性膵炎に 伴う多彩な合併症を念頭において，過大侵襲にならず 機能を温存した術式の選択が重要であると考えられ た.

\section{文献}

1) 松元定次,山口 孝,角田 司ほか：炎症性脺囊胞 の自然経過と外科治療 .胆と脺 11 : 81-85, 1990

2) Sankaran $S, W$ alt $A$ : T he natural and unnatural history of pancreatic pseudocysts. Br J Surg 62 : 37-44, 1975

3) Brandley EL, Clements JL, Gonzalez A C : The natural history of Pancreatic Pseudocysts : A unified Concept of Management. A m J Surg 137 : 135-141, 1979

4) 黑田 慧, 木村 理 : 膵囊胞性疾患の病型分類と 経過．消外 19:1653-1663,1996

5) 村田 透,長谷川洋,小木曽清二ほか：総胆管およ び十二指腸に瘻孔を形成した粘液産生脺癌の 1 例．胆と膵 $17: 1053-1058,1996$

6) 真弓俊彦, 蜂須賀喜多男, 山口晃弘ほか：10年前に 診断され，総胆管・十二指腸に穿破した粘液産生 膵腫痬の 1例 . 膵蔵 $6: 46-53,1991$

7) Ito $\mathrm{Y}$, Blackstone $\mathrm{MO}, \mathrm{Fr}$ rank $\mathrm{PH}$ et al : Mucinous 
biliary obstruction associated with a cystic adenocarcinoma of the pancreas. Gastroenter ology 73 : 1410-1412, 1977

8) Gregg JA, Carr-Locke DL, Gallagher MM : Importance of common bile duct stricture A ssociated W ith Chronic Pancreatitis. A m J Surg 141 : 199-203, 1981
9) Frey CF, Suzuki M, I saj i S : T reatment of chronic pancreatitis complicated by the common bile duct or duodenum. W orld J Surg 14 : 59—69, 1990

10) 加藤紘之, 本原敏司, 高橋利幸ほか：胆道 ・ V ater 乳頭機能を温存した十二指腸温存膵頭切除術 . 消 外 $18: 59-69,1995$

A Case Report of Pancr eatic P seudocy st Rupture into the Common Bile Duct

$$
\begin{aligned}
& \text { Hiroy uki Shikishima }{ }^{12)}, Y \text { ukihiro Kaneko }{ }^{1)},{\text { T oshij i M otohar }{ }^{1)} \text {, }}_{\text {Morio T sukada }{ }^{1)} \text { and Hiroy uki Katoh }{ }^{2)}} \\
& { }^{1)} \text { Department of Surgery, T onan Hospital } \\
& { }^{2)} T_{\text {he Second Department of Surgery , Hokkaido Univer sity }}
\end{aligned}
$$

We report a case of chronic pancreatitis with pseudocy st rupture into the common bile duct (CBD).

A 60-year-old man was admitted to our hospital because of chronic pancreatitis complicated with a pancreatic cyst. A bdominal CT scan show ed the homogeneous cy stic lesion with a smooth wall located at the pancreatic head. Endoscopic retrograde pancreatography demonstrated a pancreatic cyst which communicated with the pancreatic duct and ruptured into the CBD. T hus, the diagnosis of chronic pancreatitis with pancreatic cyst was made. Because the cyst ruptured into the CBD, we could not exclude malignant neoplasm . Pylorus-preserving pancreatoduodenectomy with D 2 ly mphnode dissection was perfomed. Pathological diagnosis of the lesion was chronic pancreatitis with pseudocy st. It should be noted that various complications can be associated with chronic pancreatitis.

Reprint requests : Hiroy uki Shikishima Department of Surgery, T onan Hospital Kita 1-Nishi 6, Chuoku, Sapporo, 060-0001 JA PA N 